\title{
How Multidimensional Approach of Entrepreneurial Orientation (EO) Effect Firm Performance: A Critical Review
}

\author{
Didip Diandra ${ }^{1 *}$ and Ahmad Azmy ${ }^{2}$
}

\begin{abstract}
Research aims: This research aims to have a better understanding of relationship between EO and firm performance, a critical review of multidimensional approach to EO-firm performance is conducted in this paper.

Design/Methodology/Approach: This is a qualitative research method which follow rigor of literature review and matrix review process from the selected papers. This paper aims to synthesize, evaluate the review, and then represent the dimension of EO on firm performance from multidimensional approach. Research findings: This study advances integrative framework to represent EO dimensions which explicates some pathways for entrepreneurs to implement EO on their business organization, else, in order to elevate sustainable growth. Also, this study concludes the most effective EO recipes for firm performance.

Theoretical contribution/ Originality: This study does not only discuss the importance of EO in firm performance but also describe on how firms able to attain best performance in uncertain condition. The author stated innovativeness and competitive aggressiveness as the best EO recipes for enhancing firm performance.

Practitioner/Policy implication: This study gives beneficial information to entrepreneurs about EO dimensions for enhancing firm performance.

Research limitation/Implication: The study is limited to ten selected papers that confirms the application of EO dimensions on firm performance. Future research should explore more factors that explain EO-Firm relationship.

Keywords: Entrepreneurial Orientation; Firm Performance; Competitive Strategy; Critical Review; Multidimensional Approach
\end{abstract}

AFFILIATION:

${ }^{1}$ Business Administration, School of Management \& Leadership, Tanri Abeng University, Jakarta Capital Special Region, Indonesia 2 Master of Management, Faculty of Economics and Business, Universitas Paramadina, Jakarta Capital Special Region, Indonesia

*CORRESPONDENCE:

didip.diandra@tau.ac.id

THIS ARTICLE IS AVAILABLE IN: http://journal.umy.ac.id/index.php/mb

DOI: 10.18196/mabis.v12i1.9743

\section{CITATION:}

Diandra, D., \& Azmy, A. (2021). How multidimensional approach of Entrepreneurial Orientation (EO) effect firm performance: A critical review. Jurnal Manajemen Bisnis, 12(1), 30-40.

\section{ARTICLE HISTORY}

Received:

05 Sep 2020

Revised:

28 Oct 2020

30 Oct 2020

Accepted:

13 Nov 2020

\section{Introduction}

Entrepreneurial orientation (EO) as a part of competitive strategy model has become an important topic in entrepreneurship (Covin \& Wales, 2018). Many literatures discussed about the relationship between EOfirm performances has been widely studied (e.g., Wiklund, 1999; Wales, 2015; Dess \& Lumpkin, 2005; Mullens, 2018), and at last, about the allocation of resources to improve firm performance (Wang, Dass, Arnett, \& Yu, 2019). 
The entrepreneurial orientation concept has been determined as the key success point for firm to make a decision or certain action in business organization (Radipere, 2014). However, they are multi dimension of EO that used in business strategy during the expansion process, to be successful, firms and its members must implement some dimension and work together to make the performance become stronger. In addition, the most popular dimensions of EO that construct the firm performance are innovativeness, proactiveness, competitive aggressiveness, risk taking, and autonomy (Lumpkin \& Dess, 1996). Furthermore, this paper will guide the reader to another factor that could enhance firm performance in this uncertain period.

This paper will portray the study done by (Dess \& Lumpkin, 2005; Mullens, 2018; Poudel, Carter, \& Lonial, 2018; Shan, Song, \& Ju, 2015; Chen, Zou, Xu, \& Chen, 2019; Wang, et al., 2019; Lisboa, Skarmeas, Saridakis, 2015; Linton \& Kask, 2016; Loong Lee, Chong, \& Ramayah, 2019; McGee \& Peterson, 2017) to understand how multidimensional entrepreneurial orientation approaches are performed to design its competitive strategy in order to elevate sustainable growth. The paper will start with depicting each study then synthesizing and reviewing all the papers at discussion.

\section{Literature Review}

Dess \& Lumpkin (2005) postulate that entrepreneurial orientation is one plausible method to enhance corporate venturing activities. It enables to stimulate corporate entrepreneurship and to foster strategic renewal. In addition, entrepreneurial orientation (EO) refers to the strategy to identify corporate ventures. EO is not only a concept, but pattern of action that generalize organization.

Dess \& Lumpkin (2005) found several dimensions of EO such as autonomy, innovativeness, proactiveness, competitive aggressiveness, and risk-taking. These five dimensions are contributed to the success of entrepreneurial orientation. The authors posit the example of virgin company emphasizes on autonomy and proactiveness. Meanwhile, Sony emphasizes EO on innovation and risk-taking. However, the firm must struggle to compete with the industry rivals in order to have sustainable growth and to lead competitive advantages.

This study explores the concept and prior research on entrepreneurial orientation. The focus of the research is on EO and firm performance relationship. It's open new direction for promising research and impact on managers and encourages economic outcomes beyond this relationship. This study also profound the important of exploring the market opportunities and firm's resource base to create new product, build sense of value and deliver value.

The study done by Mullens (2018) stated that sustainability in family business viewed as important point in the field of entrepreneurship. However, sustainability and firm performance were remaining questioned, unless the investment projects are involved. Entrepreneurial orientation becomes antecedents of investment in social and 
environmental initiatives for sustainability. Thus, this paper is not only aiming to identify the sustainability of family business but also examines the EO multidimensional function such as innovativeness, proactiveness, and risk orientation in relation to the family business contexts.

Previous studies defined EO as strategy decision-making of firms to sustain a vision and create competitive advantage (Rauch, Wiklund, Lumpkin, \& Frese, 2009; Mullens, 2018). This study reveals three dimensions of entrepreneurial orientation: risk-taking, innovativeness, and proactiveness in different way by adopting sustainable practices for social and environmental responsibilities.

This study examines the performance and sustainability of family business firm through innovation and organizational change which focuses on increasing social and environmental demands. Moreover, the study pursues sustainability initiatives which come from customers. Customers, at this point of view, may not know the products but they may seek the products which associated with environmental and social initiatives. Proactiveness of business firms in this case will create customer loyalty and positive return to the business.

This study revealed potential entrepreneurial orientation to sustainability initiatives. This research utilizes primary data, and the sample taken from retail automobile and motorcycle industries of family business. After analyzing the data, it is found that family business pursues social and environmental initiatives. Generation and year founded has high correlation with business performance and EO as independent variable with its multiple dimensions consistently used across the study.

This study profound the investment in family firm is beneficial for sustainability initiatives, and EO is as a part of social and environmental responsibility. Moreover, generation of business family and next generation may pursue long-term investment for improving business reputation, increasing social and environmental responsibility as well.

The study done by Poudel et al. (2018) aims to study on the impact of EO, technological capability, and consumer attitude on firm performance. This study extents the relationship between EO and firm performances. This paper argues the technological capability and innovations contributes to firm performance and enhance their competitive advantage. Besides that, the consumer attitude may change significantly because the impact of entrepreneurial orientation on firm performance. Entrepreneurial orientation potentially constitutes competences for entrepreneurial firm to commit increasing capabilities especially in term of technology and innovation.

This paper is exploratory study that employs qualitative methods by testing the theoretical model and quantitative methods by sending a mailing questionnaire to top level of executives and business owner. The sample is obtained from SMEs players in southeast region of United States. The data sample gathered and tested based on firm size and firm age to raise the issue of EO-firm performance, and at last the author combine the quantitative and qualitative data. 
It is found that firm financial performance as dependent variable that measures the firm performance. This statement is remained confused because EO is consist of three main point including innovativeness, proactiveness, and risk-taking. However, technological capabilities, construction of 'consumer attitude dynamism' and firm growth are as exploratory variables in this research.

The authors recommend EO to maximize the firm performance engagement, besides also extent the financial performance of firm. In addition, it is suggested integration of EO-firm performance with more theoretical framework and explores its process, then finally effect the consumer behavior.

The study done by Shan et al. (2015) illustrates innovation as a missing link in between entrepreneurship orientation and performance relationship. Speed innovation is not discussed in many papers related to entrepreneurial orientation. However, speed innovation means the speed of new products to enter the market or on the other word, to make the products available in the market in the fastest time. For that reason, it is important to understand innovation speed in the context of organizational performance. Hence, this paper aims to provide understanding about the role of innovation speed in relation to entrepreneurial orientation and organizational performance.

The authors argue new product development (NPD) as a mediating concept that effect and intervenes the relationship between EO and performance. The authors describe the hypotheses into innovativeness, autonomy, risk-taking, proactiveness, and competitive aggressiveness. The only innovativeness has a negative effect on speed innovation, others have a positive effect including innovation has a positive effect on performance.

The authors explain the concepts that consist of five dimensions. The data collected and the sample is taken from new companies out of 1000 companies from Dun and Bradstreet's (D\&B) database list in 2007. This study employs control variable such as market growth, technological turbulence, and industry dummies to examine the innovation speed on organizational performance.

It is found that 'superior performance is drive by faster innovation' (Shan, et al., 2015), However, autonomy and competitive aggressiveness only increase the innovation speed. This study also found the important of technological process innovation to respond the market demands. But at the end, this study found proactiveness as the largest contributor to innovation speed due to ability to take opportunities offered in the market and initiative taken by high level of organization. Thus, innovation speed is a missing link between EO and organizational performance.

The study done by Chen et al. (2019) stated that EO in international context is very rare and scare. Multinational Corporation (MNCs) is the companies that operate in the global market with higher competitive advantage, exploring foreign market with fast changing attitude and behavior of international customers. However, instead of positive effect for organizational performance, EO for multinational companies is remained unclear. The authors argue to improve the importance of EO in response to the global market. Thus, 
this paper not only aims to identify the research gap, but also to investigate the antecedent and effect of EO on MNC's performance. Then finally moderate effect on the relationship between $\mathrm{EO}$ and $\mathrm{MNC}^{\prime}$ 's performance.

This study defines EO as a strategic orientation to improve the performance of organization and define EO with the same three dimensions like previous researchers such as innovativeness, proactiveness, and risk-taking. The authors argue the empirical research of EO in international context is limited and divided EO into a positive effect on firm performance, while others imply negative effect. In addition, this study also exhibits the relationship mechanism for EO that impact performance. For instance, technological capability is investigated as the new role model of EO in international contexts. This study conceptualizes EO as the role model for exploring new opportunities for a firm in global market.

This study defines MNCs integration mechanism in three areas such as technological flexibility, centralization, and subsidiary cooperation. The only centralization has a negative influence on MNCs entrepreneurial orientation, and others are positive. The last hypotheses examine the relationship between EO and MNC performance and found that EO is positively influence on MNC's performance in the global market. Moreover, this study also exposes the moderating effect from EO and MNC performance and found two variable that has negative and positive moderate effect on $\mathrm{EO}$ and $\mathrm{MNC}$ performance they are international experience and external competition.

This study gathered the data from MNC in manufacturing industries. Survey questionnaire are collected and personal interview with executive of MNC are conducted. They were 126 completed questionnaire or $29.1 \%$ response rate. The authors used PLS to analyses the data. The result of analysis shows that EO is determinant factor for firm performance. The finding of this study disclosed two major information for EO, first, important knowledge of EO for improving firm performance, and second, the moderator effect that extent the EO-firm performance relationship.

The study done by Wang et al. (2019) postulates the role of EO in analyzing the strategic emphases of firm. It is enabling the companies to choose value-creation or valueappropriation. In addition, the authors contend that many managers encourage more value appropriation rather than value creation. Thus, this paper aims to study both value in the concept of relativity which is called 'relative strategic emphases'. Furthermore, this paper examines hypotheses between EO and firm's relative strategic emphases on value creation versus value appropriation.

The sample of this study is taken from S\&P 500 index database companies and the data collected from annual report that allow investigation of EO. The control variable was deployed and analyzed. The results of analysis show first, the positive influence of EO on strategic emphasis, second, negative interaction of EO and compensation strategy, and last, positive interaction between EO and capital market. 


\section{Diandra \& Azmy}

How Multidimensional Approach of Entrepreneurial Orientation ...

This study identified that allocation of resources can help improving firm performance. Moreover, managers in this context should focus on value creation rather than value appropriation. In addition, allocation of resources is as an important factor of entrepreneurial orientation.

The study done by Lisboa et al. (2015) stated that entrepreneurial orientation is always construct in three dimensions that is innovativeness, proactiveness, and risk taking. However, the authors offered different understanding about the role of EO in firm performance. The authors argue to address alternative dimensions of EO for firm to high performance. In addition, resource-based view (RBV) and dynamic capabilities (DC) theories are investigated to find a complex antecedent of EO and firm performance.

This study constructs conceptual framework to measure dimensions of EO to profitability (firm performance). The sample of study is taken from manufacturing firms in Portugal. The data is collected from Portuguese National Statistics Institute database which comprises 1271 firms out of 2931 firm list. Moreover, this study applied fsQCA (fuzzy set qualitative comparative analysis) to examine the relationship between variables.

This study revealed some alternative pathways to performance; product development exploration; product development exploitation; new-product differentiation; new product speed to market; and finally, profitability. Moreover, this study also employs SEM as supplementary analysis. As a result, control variables are analyzed respectively.

The study done by Linton and Kask (2016) configures EO and competitive strategy for high firm performance in the form of entrepreneurship and management research. Both authors argue the competitive strategy for high performance is not revealed yet like EO of the firm. The authors used generic competitive strategy by Porter (1980) to describe the firm competitive strategy and performance. This paper is explanatory study that employs qualitative methods on its description.

This paper defines configuration theory that combine EO and competitive strategy altogether. However, this research has no different with previous research that expose the three dimensions of EO such as innovativeness, proactiveness, and risk taking. On the other hands, competitive strategy employs cost leadership, differentiation, and mix strategy. Both theories are explained together in the form of configuration and analyzed by using typology concept respectively.

This study collects the data by survey and the sample are taken from 310 sporting retailers in Sweden. It is found that there is several indications that on how to combine both configured strategies. High firm performance is indicated by the combination of differentiation strategy, innovativeness, and proactiveness, while cost leadership and risk taking are not. In addition, unique combination of both strategies will lead to high performance of firms.

The study done by Loong Lee et al. (2019) aims to study on how EO effect on Malaysian manufacturing sector's performance, and also to know how transformational leadership 
effect on firm performance. This paper examines multiple function of EO on firm performance. However, instead of positive effect of EO on firm performance, Malaysian manufacturing sectors still need other factors to support the EO-firm performance.

This study explores the five dimensions of EO to firm performance like previous research such as innovative, proactive, risk taking, autonomy, and competitive aggressiveness. The authors develop the research model with hypotheses that all five dimensions have a positive effect on firm performance.

The questionnaires of this study were taken from the Malaysian manufacturing industry at organizational level. There were 321 questionnaires collected. After analyzing the data, it is found that the three dimensions of EO such as autonomy, proactiveness, and competitive aggressiveness have a small effect on firm performance, while others are not. Finally, this study found that being innovative and risk taking is not significant in improving firm performance.

The study done by McGee and Peterson (2017) postulates the long-term effect of entrepreneurially self-efficacy (ESE) and entrepreneurial orientation (EO) on firm performance. The study divided the firm condition into two categories; very young firms; and new firms mature. This paper aims to study the effect of entrepreneurial self-efficacy at very early phase of venture performance, and at the same time explore the long-term relationship of EO to firm performance.

This study defines multiple definitions of self-efficacy and its level, but finally defines selfefficacy in entrepreneurship as a decision to start new venture, in the other word, launch a start-up in early phase of venture. At the same time, the authors define EO like previous research in three dimensions they are innovativeness, proactiveness, and risk taking. This study examines the effect of ESE and EO on firm performance in year one and three year and five year later.

The data is collected by survey based on firm size and age (control variables), then the sample is taken from new entrepreneurs in Southwestern city of United States in three waves, 2016 with 311 respondents, 2019 with 181 respondents, and 2011 with 89 respondents. After analyzing the data, it is found that ESE has positive effect on firm performance in all year. On the other hands, EO does not support firm performance only in year one, but others are just same like ESE. Thus, both ESE and EO simultaneously effects on firm performance.

\section{Research Methods}

This is a qualitative research method which follow rigor of literature review and matrix review process from the selected papers. This paper aims to synthesize, evaluate the review, and then represent the dimension of EO on firm performance from multidimensional approach. The data used in this study is collected from electronic 
business database sources such as Google Scholars, Elsevier ScienceDirect, Emerald Insight, SAGE Journals, and Management International Review (MIR).

\section{Results and Discussion}

Dess and Lumpkin, (2005); Poudel et al. (2018); Lisboa et al. (2015); McGee and Peterson, (2017) upply the readers on what might the business organization hope after implementing EO on their business strategies for improving firm performance. However, they just discover the effect of EO on firm performance. Mullens (2018) questioning the role of EO on firm performance, unless the investment on social and environmental initiatives are involved. Wang et al. (2019) suggest value creation and allocation of resources could improve firm performance. Moreover, Shan et al. (2015) emphasize on speed innovation could drive superior performance of firm. On the other hands, Linton and Kask (2016) configures EO with competitive strategy for high performance of firms like Malaysian manufacturers require other factors to support firm performance (Loong Lee et al., 2019). Loong Lee et al. (2019) suggest leadership and culture of organization could boost the firm performance. However, the five dimensions of EO is not fully support for firm performance, especially in international context (Chen et al., 2019). Yet, it is beneficial to share the alternative factors that could improve firm performance. In sequence, through multidimensional approach of EO on firm performance, the readers could capture the big picture of EO and how it's performed. At the end, those processes of EO are not only impact on positive effect of firm performance but also elevate the sustainable growth of business organization as well.

These ten papers are relatively straight forward research and most of the papers are adopting mix model to analyses the gap and explain EO-firm performance. However, to enhance the benefits of the readers, it would be more beneficial if (Dess \& Lumpkin, 2005) not only discussing on EO-firm performance and relationship but also about sustainability of firm as suggested by (Mullens, 2018), innovation by (Shan et al., 2015), value creation by (Wang et al., 2019 and product engagements by (Lisboa et al., 2015). Thus, holistic picture of multi dimension of EO for long-term relationship like what (McGee \& Peterson, 2017) suggested could be defined for high performance of firms (Linton \& Kask, 2016). In addition, (Chen et al., 2019) study of EO in International context could be easier because of redundant information of multidimensional EO and its supportive factors are supplied in this paper to the readers, business owners, managers, and off course, for entrepreneurs.

Thus, this study finally portrait the representation of EO on firm performance based on previous research. This study explicates some pathways for business organization. However, these studies are suggesting the complexity of EO-firm relationship. In addition, other factors are indicated as alternative dimensions that support EO-Firm performance. 
Table 1. Representation of Entrepreneurial Orientation

\begin{tabular}{|c|c|c|c|}
\hline No & Authors & EO dimensions & Other Factors \\
\hline 1 & $\begin{array}{l}\text { (Dess \& } \\
\text { Lumpkin, 2005) }\end{array}$ & $\begin{array}{l}\text { Innovativeness, Proactiveness, } \\
\text { Competitive Aggressiveness, and } \\
\text { Risk-Taking }\end{array}$ & Market Opportunities \\
\hline 2 & (Mullens, 2018) & $\begin{array}{l}\text { Innovativeness, Proactiveness, } \\
\text { and Risk Orientation }\end{array}$ & $\begin{array}{l}\text { Social and Environmental } \\
\text { Responsibilities }\end{array}$ \\
\hline 3 & $\begin{array}{l}\text { (Poudel, Carter, } \\
\text { \& Lonial, 2018) }\end{array}$ & $\begin{array}{l}\text { Innovativeness, Proactiveness, } \\
\text { and Risk-Taking }\end{array}$ & $\begin{array}{l}\text { Technological Capability, } \\
\text { Innovation, and Firm Financial } \\
\text { Performance }\end{array}$ \\
\hline 4 & $\begin{array}{l}\text { (Shan, Song, \& } \\
\text { Ju, 2015) }\end{array}$ & $\begin{array}{l}\text { Innovativeness, Autonomy, Risk- } \\
\text { Taking, Proactiveness, and } \\
\text { Competitive Aggressiveness }\end{array}$ & Speed Innovation \\
\hline 5 & $\begin{array}{l}\text { (Chen, Zou, Xu, } \\
\text { \& Chen, 2019) }\end{array}$ & $\begin{array}{l}\text { Innovativeness, Proactiveness, } \\
\text { and Risk-Taking }\end{array}$ & $\begin{array}{l}\text { Technological Flexibility, } \\
\text { Centralization, and Subsidiary } \\
\text { Cooperation }\end{array}$ \\
\hline 6 & $\begin{array}{l}\text { (Wang, Dass, } \\
\text { Arnett, \& Yu, } \\
\text { 2019) }\end{array}$ & $\begin{array}{l}\text { Innovativeness, Proactiveness, } \\
\text { and Risk-Taking }\end{array}$ & $\begin{array}{l}\text { Value Creation, and Allocation } \\
\text { of Resources }\end{array}$ \\
\hline 7 & $\begin{array}{l}\text { (Lisboa, } \\
\text { Skarmeas, \& } \\
\text { Sarikadis, 2015) }\end{array}$ & $\begin{array}{l}\text { Innovativess, Proactiveness, and } \\
\text { Risk Taking }\end{array}$ & $\begin{array}{l}\text { Product Development } \\
\text { Exploration, Product } \\
\text { Development Exploitation, } \\
\text { New-Product Differentiation, } \\
\text { New Product Speed To Market }\end{array}$ \\
\hline 8 & $\begin{array}{l}\text { (Linton \& Kask, } \\
\text { 2016) }\end{array}$ & $\begin{array}{l}\text { Innovativeness, Proactiveness, } \\
\text { and Risk Taking }\end{array}$ & $\begin{array}{l}\text { Competitive Strategy; Cost } \\
\text { Leadership, Differentiation, and } \\
\text { Mix Strategy }\end{array}$ \\
\hline 9 & $\begin{array}{l}\text { (Loong } \quad \text { Lee, } \\
\text { Chong, } \quad \& \\
\text { Ramayah, 2019) }\end{array}$ & $\begin{array}{l}\text { Innovative, Proactive, Risk Taking, } \\
\text { Autonomy, and Competitive } \\
\text { Aggressiveness }\end{array}$ & $\begin{array}{l}\text { Leadership, and Culture of } \\
\text { Organization }\end{array}$ \\
\hline 10 & $\begin{array}{l}\text { (McGee \& } \\
\text { Peterson, 2017) }\end{array}$ & $\begin{array}{l}\text { Innovativeness, Proactiveness, } \\
\text { and Risk Taking. }\end{array}$ & $\begin{array}{l}\text { Entrepreneurial Self-Efficacy } \\
\text { (ESE) }\end{array}$ \\
\hline
\end{tabular}

Source: Researcher Modification

\section{Conclusion}

The ten articles do not only discuss the importance of EO in firm performance but also describe on how firms able to attain best performance in uncertain condition. In general, these articles propose to utilize the five dimensions of EO, or some of it, to enhance firm performance. However, they also use different factors; for instance, Shan et al. (2015) apply the speed innovation instead of innovativeness to gain superior performance. Furthermore, those articles agree that EO play important roles in designing firm performance. In short, (Poudel et al., 2018) concept of innovation, (Shan et al., 2015) concept of speed innovation, and (Lisboa et al., 2015) concept of new product speed to market is important in developing theory of entrepreneurial orientation. Thus, innovation and firm performance (Huang \& Wang, 2011) must be discussed separately. Similarly, the rest of the articles confirm the factors of competitive strategy contribute to EO-firm 
How Multidimensional Approach of Entrepreneurial Orientation ...

performance. Yet, only (Wang et al., 2019) mention allocation of resources that linked to EO-firm performance.

Finally, based on the above discussion and previous research, the author stated innovativeness and competitive aggressiveness (competitive strategy) as the best EO recipes for enhancing firm performance. Even though, all articles explain on how EO affects firm performance, but they have different context in representing entrepreneurial orientation concept. Thus, the study of multidimensional of EO is left questioned, especially during the interaction between dimensions and other factors. Deeper analysis of EO dimensions for firm performance is required (Putnins \& Sauka, 2019) and further research is needed (Solikahan \& Mohammad, 2019).

At the end, this research is a critical review research of Entrepreneurial Orientation. The study is limited to ten selected papers that confirms the application of EO dimensions on firm performance. Future more factors that research should explain support EO-Firm relationship.

\section{References}

Chen, L., Zou, S., Xu, H., \& Chen, Y. (2019). Entrepreneurial orientation in multinational corporations: Antecedents and effects. Management International Review, 60(1), 123-148. https://doi.org/10.1007/s11575-019-00397-4

Covin, J. G., \& Wales, W. J. (2018). Crafting high-impact entrepreneurial orientation research: Some suggested guidelines. Entrepreneurship theory and practice, 43(1), 3-18. https://doi.org/10.1177/1042258718773181

Dess, G. G., \& Lumpkin, G. T. (2005). The role of entrepreneurial orientation in stimulating effective corporate entrepreneurship. Academy of Management Perspectives, 19(1), 147-156. https://doi.org/10.5465/ame.2005.15841975

Huang, S. K., Wang, Y. L. (2011). Entrepreneurial orientation, learning orientation, and innovation in small and medium enterprises. Procedia Social and Behavioral Sciences, 24, 563-570. https://doi.org/10.1016/i.sbspro.2011.09.004

Linton, G., \& Kast, J. (2016). Configurations of entrepreneurial orientation and competitive strategy for high performance. Journal of Business Research, 70(1), 168-176. https://doi.org/10.1016/i.jbusres.2016.08.022

Lisboa, A., Skarmeas, D., Saridakis, C. (2015). Entrepreneurial orientation pathways to performance: a fuzzy-set analysis. Journal of Business Research, 69(4), 1319-1324. https://doi.org/10.1016/i.jbusres.2015.10.099

Loong Lee, W., Chong, A. L., \& Ramayah, T. (2019). The effects of entrepreneurial orientation on the performance of the Malaysian manufacturing sector. Asia-Pacific Journal of Business Administration, 11(1), 30-45. https://doi.org/10.1108/APJBA-06$\underline{2018-0099}$

Lumpkin, G.T., \& Dess, G.G. (1996). Clarifying the entrepreneurial orientation construct and linking it to performance. Academy of Management Review, 21(1), 135-172. https://doi.org/10.2307/258632

McGee, J. E., \& Peterson, M. (2017). The long-term impact of entrepreneurial self-efficacy and entrepreneurial orientation on venture performance. Journal of Small Business Management, 57(3), 720-737. https://doi.org/10.1111/jsbm.12324

Mullens, D. (2018). Entrepreneurial orientation and sustainability initiatives in family firms. 
Journal of Global Responsibility, 9(2), 160-178. https://doi.org/10.1108/JGR-03-20170020

Porter, M. E. (1980). Competititve strategy. New York: Free Press.

Poudel, K. P., Carter, R., \& Lonial, S. (2018). The impact of entrepreneurial orientation, technological capability, and consumer attitude on firm performance: A multi-theory perspective. Journal of Small Business Management, 57(S2), 268-295. https://doi.org/:10.1111/jsbm.12471

Putnins, T. J., \& Sauka, A. (2019). Why does entrepreneurial orientation affect company performance. Strategic Entrepreneurship Journal, 1-25. https://doi.org/10.1002/sej.1325

Radipere, S. (2014). The effect of entrepreneurial orientation on business performance. Mediterranian Journal of Social Sciences, 5(16), 141-152. https://doi.org/10.5901/mjss.2014.v5n16p141

Rauch, A., Wiklund, J., Lumpkin, G. T., \& Frese, M. (2009). Entrepreneurial orientation and business performance: an assessment of past research and suggestions for the future. Entrepreneurship Theory and Practice, 33(3), 761-787. https://doi.org/10.1111/j.15406520.2009.00308.x

Shan, P., Song, M., Ju, X. (2015). Entrepreneurial Orientation and Performance: Is Innovation Speed a Missing Link?. Jurnal of Business Research, 69(2), 683-690. https://doi.org/10.1016/i.jbusres.2015.08.032

Solikahan, E. Z., \& Mohammad, A. (2019). Development of entrepreneurial orientation. International Journal of Applied Business \& International Management, 4(1), 31-37. https://doi.org/10.32535/ijabim.v4i1.380

Wales, W. J. (2015). Entrepreneurial orientation: A review and synthesis of promising research directions. International Small Business Journal, 34(1), 3-15. https://doi.org/10.1177/0266242615613840

Wang, X., Dass, M., Arnett, D. B., \& Yu, X. (2019). Understanding firms' relative strategic emphases: an entrepreneurial orientation explanation. Industrial Marketing Management, 84(2020), 151-164. https://doi.org/10.1016/j.indmarman.2019.06.009

Wiklund, J. (1999). The sustainability of the entrepreneurial orientation-performance relationship. Entrepreneurship Theory \& Practices, 24(1), 37-48.

https://doi.org/10.1177/104225879902400103 